\title{
In situ Electron Microscopic Observation of Negatively Stained Tissue Culture Cells Contaminated with Mycoplasmas
}

\author{
By H. TAKAYAMA, ${ }^{1 *}$ T. KATSUMOTO,${ }^{1} \mathrm{~K}$. OHNO,${ }^{2}$ A. NAKASO,${ }^{3}$ \\ A. TAKAGI ${ }^{1}$ AND G. KIMURA ${ }^{4}$ \\ ${ }^{1}$ Department of Bacteriology, ${ }^{2}$ Division of Child Neurology, and ${ }^{3}$ Department of Virology, \\ Tottori University School of Medicine, Yonago 683, Japan \\ ${ }^{4}$ Department of Virology, Medical Institute of Bioregulation, Kyushu University, Fukuoka 812, \\ Japan
}

(Received 16 May 1983)

\begin{abstract}
A simple, fast, and in situ method of detecting the inapparent infection of cultured cells with mycoplasmas is reported. Animal cells grown on Formvar-coated electron microscopic grids were directly fixed with glutaraldehyde, negatively stained with phosphotungstic acid and examined by transmission electron microscopy. Cells contaminated with mycoplasmas could be discriminated from uncontaminated cells. The micro-organisms in the negatively stained preparations corresponded with those revealed by thin sectioning, and the distribution of mycoplasmas in cultured cells coincided with those revealed by the Hoechst staining method. Most of the highly resolved mycoplasmas were polymorphic, and closely associated with host cells; often more than 500 organisms per host cell were seen.
\end{abstract}

\section{INTRODUCTION}

Mycoplasmas are common contaminants of animal cell cultures, and can produce severe cytopathic changes (Macpherson, 1966; Stanbridge, 1971), such as metobolic (Hakala et al., 1963) karyological (Schneider et al., 1974), and morphological (Zucker-Franklin et al., 1966) aberrations. Electron microscopic techniques by thin sectioning, negative staining and scanning microscopy are useful methods for detecting and identifying mycoplasmas in tissue cultured cells.

Whole cells cultured on Formvar-coated substrate have been visualized by electron microscopy in situ (Buckley \& Porter, 1975; Katsumoto et al., 1978). The present report is concerned with application of the method to study cells contaminated with mycoplasmas.

\section{METHODS}

Mammalian cells and cultures. A total of 50 cell lines (3Y1, 3Y1-derivatives, BSC-1, AGMK, 3T3 and others) were examined. Cells were recovered by thawing from stocks stored at $-90^{\circ} \mathrm{C}$. Cultures methods were as previously described (Kimura \& Itagaki, 1975); briefly, cells were cultured in Dulbecco's modified Eagle's medium with $0 \cdot 1 \%(\mathrm{w} / \mathrm{v})$ glucose (GIBCO) supplemented with $10 \%(\mathrm{v} / \mathrm{v})$ heat-inactivated foetal calf serum in a humidified incubator flushed with a $\mathrm{CO}_{2}$-air mixture. Unless otherwise stated, plastic tissue culture dishes were used for monolayer cultures.

Micoplasmas. Mycoplasma hominis type 1-c, (obtained from M. Nakamura, Department of Microbiology, Kurume University School of Medicine) and unidentified mycoplasmas in animal cell culture were cultured in enriched PPLO broth or agar (Difco). The media were composed of PPLO broth, horse serum and freshly prepared yeast extract $(70: 20: 10$, by vol.) supplemented with $0.0125 \%(w / v)$ thallium acetate (Wako Co., Osaka, Japan) and $1000 \mathrm{U}_{\text {penicillin } \mathrm{G} \mathrm{ml}}^{-1}$ (Meiji Seika Co., Tokyo, Japan). The enriched PPLO agar contained $70 \mathrm{vol}$. PPLO agar instead of PPLO broth (Ichimaru \& Nakamura, 1979).

Electron microscopy. For negative staining, animal cells grown on plastic dishes were dispersed with a mixture of $0.02 \%(\mathrm{w} / \mathrm{v})$ EDTA and $0.05 \%(\mathrm{w} / \mathrm{v})$ trypsin in phosphate-buffered saline, and inoculated on electron microscopic 

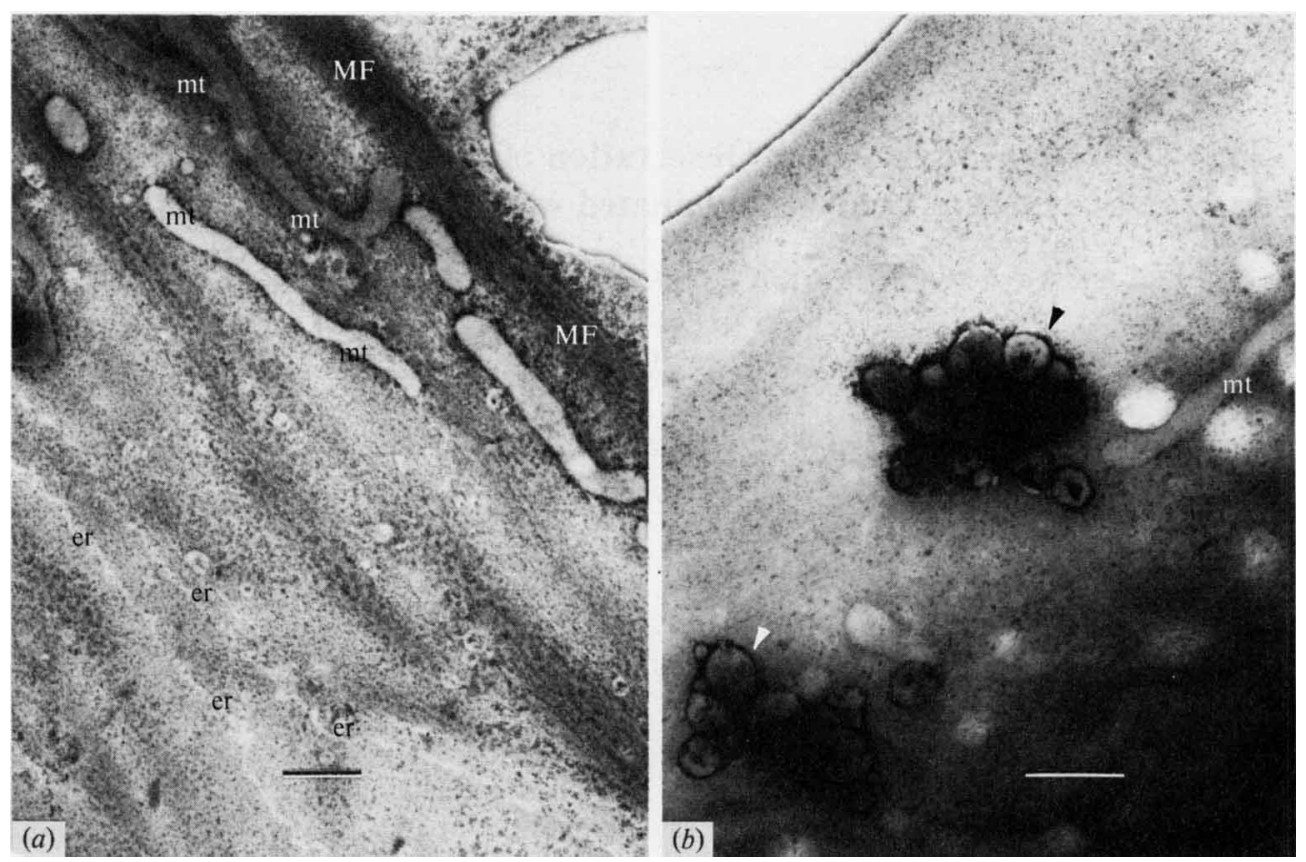

Fig. 1. Control cells and artificially infected (contaminated) cells in negatively stained preparations. Rat embryo fibroblast cells, line 3Y1-B clone 1-6-2, were examined. (a) Cellular components, e.g., mitochondria (mt), bundles of microfilaments (MF), and endoplasmic reticulum (er). (b) The cell line was artificially infected with Mycoplasma hominis type 1-c, and examined by negative staining; the added mycoplasmas were detected as small aggregative forms (arrow heads). The bar markers represent $1 \cdot 0 \mu \mathrm{m}$.

grids coated with thin Formvar films. After the desired incubation periods, they were fixed in $3 \%(\mathrm{w} / \mathrm{v})$ glutaraldehyde, $\mathrm{pH} 7 \cdot 2$, at $37^{\circ} \mathrm{C}$ for $1 \mathrm{~h}$, stained with $3 \%(\mathrm{w} / \mathrm{v})$ phosphotungstic acid for $30 \mathrm{~s}$, and then examined with a Hitachi HU-12A type transmission electron microscope operated at $100 \mathrm{kV}$. These negative staining procedures have been described in detail (Katsumoto et al., 1978).

Cells to be sectioned were grown on dishes, fixed in $3 \%(\mathrm{v} / \mathrm{v})$ glutaraldehyde, scraped from the bottom of the dishes with a rubber policeman, and postfixed in $1 \%(\mathrm{w} / \mathrm{v})$ osmic acid in cacodylate buffer at room temperature for $1 \mathrm{~h}$. They were dehydrated in 30-100\% (v/v) graded ethanol series, embedded in Epon 812 (Oken, Tokyo, Japan), and sectioned by a ultramicrotome. The sections were stained in uranylacetate and lead citrate solutions (Katsumoto et al., 1978).

Other methods for detecting mycoplasmas. Some cell lines were examined by the Hoechst 33258 staining method (Chen, 1977), by autoradiography (Nardone et al., 1965), and by the cultural method.

\section{RESULTS AND DISCUSSION \\ Artificially infected cells}

Line 3Y1-B clone 1-6-2, judged mycoplasma-free by fluorescent Hoechst 33258 staining and autoradiography, was used for control experiments. The healthy cells were grown and examined by negative staining. Cellular components, other than ribosomes, were observed, e.g., mitochondria, cytoplasmic bodies, endoplasmic reticulum, microtubules, and microfilaments, and corresponded with those in thin sectioned preparations (Katsumoto et al., 1978) (Fig. 1 a).

Mycoplasma hominis was cultured in PPLO broth, added to the healthy cell cultures of line 3Y1-B clone 1-6-2, further cultured for $4 \mathrm{~d}$, and then examined by the negative staining. The added mycoplasmas were detected as small aggregates, possibly on the cell surface (Fig. $1 b$ ). These mycoplasmas appear nearly identical to those in the negatively stained preparations of pure cultures of mycoplasmas described by other workers (Boatman et al., 1971). This method is applicable to the screening of mycoplasma contaminants in animal cell cultures. 
Table 1. Results of four methods for detection of mycoplasmas in animal cells

Animal cell lines were cultured, and examined by negative staining, autoradiography, Hoechst 33258 staining, and culture isolation. The symbol + or - indicates whether the cell line is positive or negative for mycoplasma contamination, as judged by each method.

Cell line (stock no.)

C3H2K p86 (1-28)

MDCK (8-20)

Py-3Y1-117 (8-8)

640-3Y1-2 (6-25)

$3 Y 1-B$ cl 1-6 (1-20)

CV-1 cl 1 (2-1)

$\mathrm{CV}-1$ (5-7)

640-3Y1-4 (8-2)

BSC-1 p66 (11-20)

fl $8(11-9)$

BSC-B (3-3)

SV-3Y1-3 (9-29)

640-GMK-U105-2 (10-14)

$3 Y 1-B$ cl l (2-7)

640-GMK-U18-2 (12-12)

\begin{tabular}{|c|c|c|c|}
\hline \multicolumn{2}{|c|}{$\begin{array}{l}\text { Negative } \\
\text { staining* }\end{array}$} & \multicolumn{2}{|c|}{ Autoradiography $\dagger$} \\
\hline+ & I & + & $\mathrm{N}+: \mathrm{C}+$ \\
\hline+ & $\mathrm{F}$ & + & $\mathrm{N}+: \mathrm{C}+$ \\
\hline+ & I & + & $\mathrm{N}+: \mathrm{C}+$ \\
\hline+ & I & + & $\mathbf{N}+\mathbf{C}+$ \\
\hline+ & I & + & $\mathrm{N}-: \mathrm{C}+$ \\
\hline+ & I & + & $\mathrm{N}-: \mathrm{C}+$ \\
\hline+ & I & + & $\mathrm{N}-: \mathrm{C}+$ \\
\hline+ & $\mathrm{I}$ & + & $\mathrm{N}-: \mathrm{C}+$ \\
\hline+ & I & + & $\mathrm{N}-: \mathrm{C}+$ \\
\hline+ & I & + & $\mathrm{N}-: \mathrm{C}-$ \\
\hline+ & I & + & $\mathrm{N}-: \mathrm{C}-$ \\
\hline+ & I & + & $\mathrm{N}-: \mathrm{C}-$ \\
\hline+ & I & + & $\mathrm{N}-: \mathrm{C}-$ \\
\hline+ & $I$ & - & $\mathrm{N}+: \mathrm{C}-$ \\
\hline+ & $\mathbf{E}$ & - & $\mathrm{N}+: \mathrm{C}-$ \\
\hline
\end{tabular}

Hoechst staining Culture

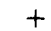

$+$

$+$

$+$

$+$

$+$

$+$

$+$

$+$

* I indicates mycoplasmas with irregular shape, $\mathrm{E}$ and $\mathrm{F}$ indicate elongate and filamentous shapes, respectively.

$\dagger \mathrm{N}+$ indicates the presence of nuclear label with silver grains, and $\mathrm{N}-$ the absence. $\mathrm{C}+$ indicates the presence of cytoplasmic label with silver grains, and $\mathrm{C}-$ the absence.

\section{Cells inapparently infected with mycoplasmas}

A total of 50 animal cell lines including those to be infected with mycoplasmas were examined by negative staining, and some cell lines were also examined by the Hoechst 33258 staining method, autoradiography, and by the culture method.

Mycoplasmas were detected in 15 out of the 50 cell lines. The results from negative staining and Hoechst staining were in complete agreement in all cases examined. Cell lines judged as apparently infected by negative staining are listed in Table 1, and the results of the four procedures are summarized.

It was found that autoradiography and the culture method led to erroneous conclusions, and that no significant correlations were observed between the morphological features of mycoplasmas and the patterns of silver grains in autoradiographs (Table 1). In a number of cases, most of the animal cells had more than 500 organisms per host cell; however, in a few cases cells had less than 50 organisms per host cell. Mycoplasmas revealed by negative staining often showed irregular profiles (Fig. $2 a$ ). These variations in shape probably reflect true morphological differences rather than preparative artefacts. Sometimes, elongate forms (Fig. $2 b$ ) or filamentous forms (Fig. $2 c$ ) could be found on the cell surface or extracellular space. The cells shown in Fig. 2(a) were thin sectioned and examined. Mycoplasmas were seen in the outer cell surface (Fig. $3 a$ ), but in some cases they were also seen in the endocytic vacuoles (Fig. $3 b$ ).

To examine whether fluorescent bodies in the Hoechst stained preparations coincide with mycoplasmas in the negatively stained preparations, an animal cell line, 640-3Y1-2, infected with mycoplasmas, was examined by the two methods. The greenish fluorescent bodies in the Hoechst 33258 stained preparations coincided well with the ultrastructural features in the negatively stained preparations (Fig. $4 a, b$ ). To obtain direct evidence, the animal cells were stained with Hoechst 33258 stain, and photographed by fluorescent microscopy, and the same preparations were then negatively stained and examined by electron microscopy; fluorescent bodies were confirmed as mycoplasmas.

The established techniques for the detection and identification of mycoplasmas include chemical (Barile \& Schimke, 1963), immunological methods (Barile et al., 1962), scanning electron microscopy (Brown et al., 1974), autoradiography (Nardone et al., 1965), and Hoechst 


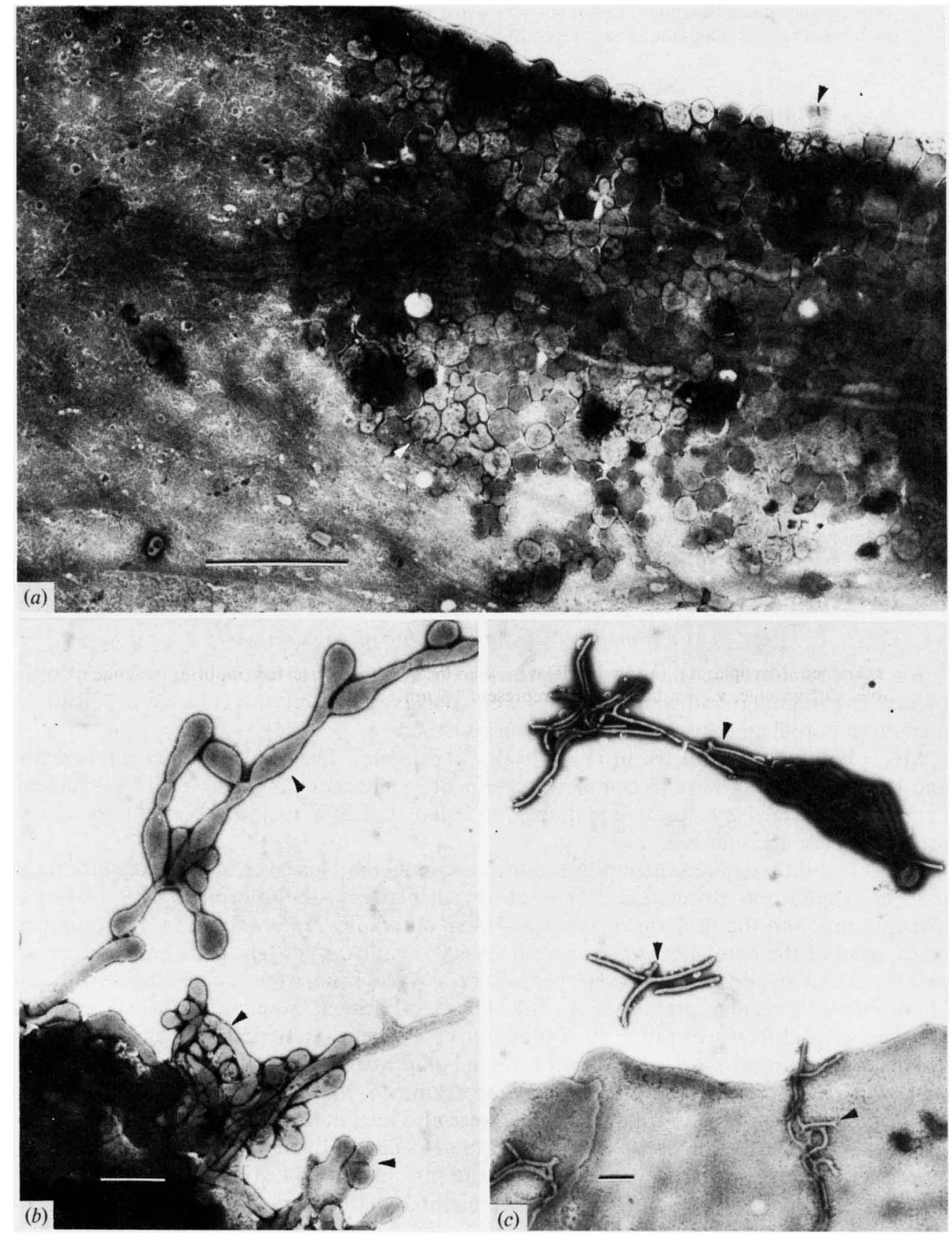

Fig. 2. Mycoplasmas detected by negative staining. Mycoplasmas (arrow heads) had irregular shape $(a$, line BSC-1 p66), sometimes elongate shape ( $b$, line 640-GMK-U18-2) or filamentous shape $(c$, line MDCK). The bar marker represents $5.0 \mu \mathrm{m}$ in $(a)$ and $1.0 \mu \mathrm{m}$ in $(b)$ and $(c)$. 

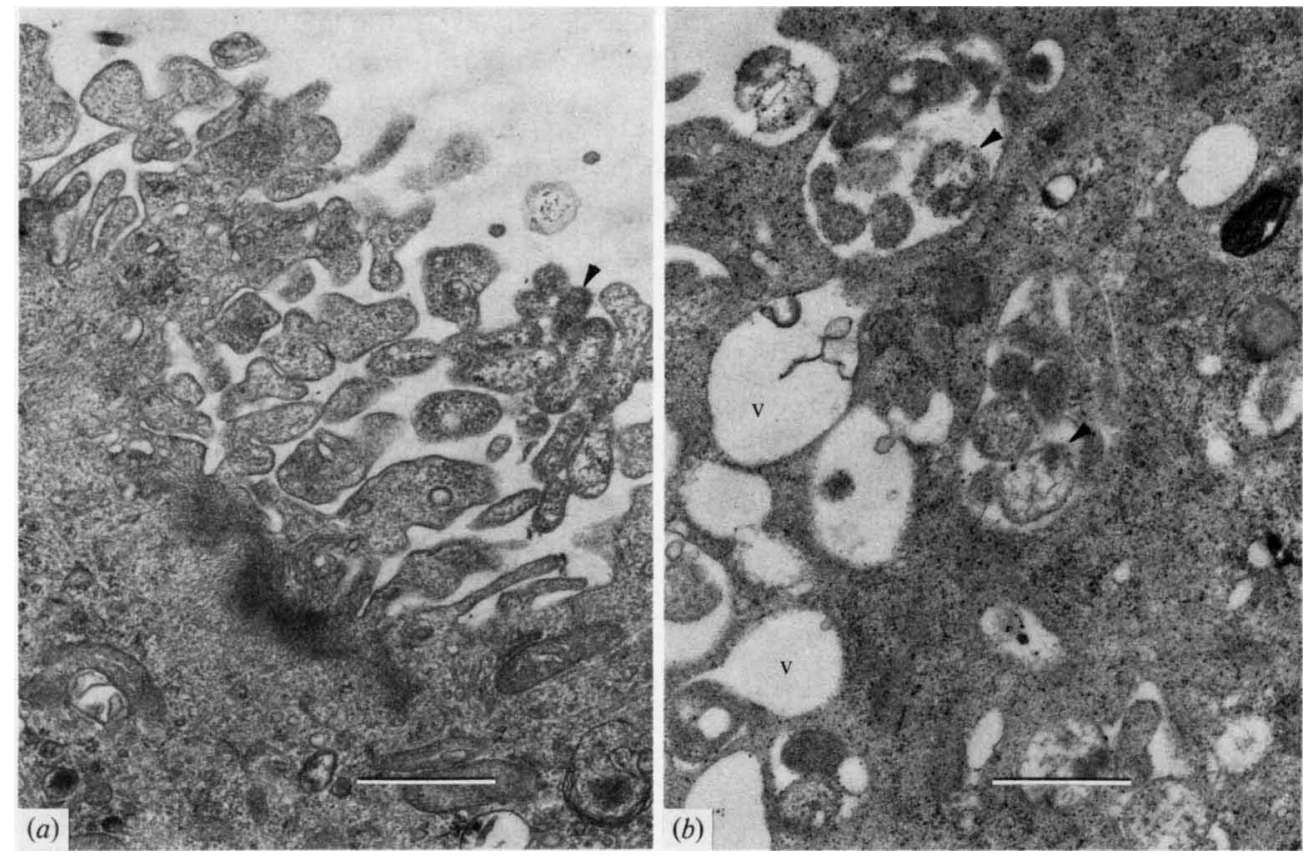

Fig. 3. Cells infected with mycoplasmas in thin sectioned preparations. The cell line shown in Fig. 2(a) was examined. Mycoplasmas (arrow heads) were seen in the outer cell surface ( $a$, or in the endocytic vacuoles $(b)$; vacuole, $v$. The bar markers represent $1.0 \mu \mathrm{m}$.
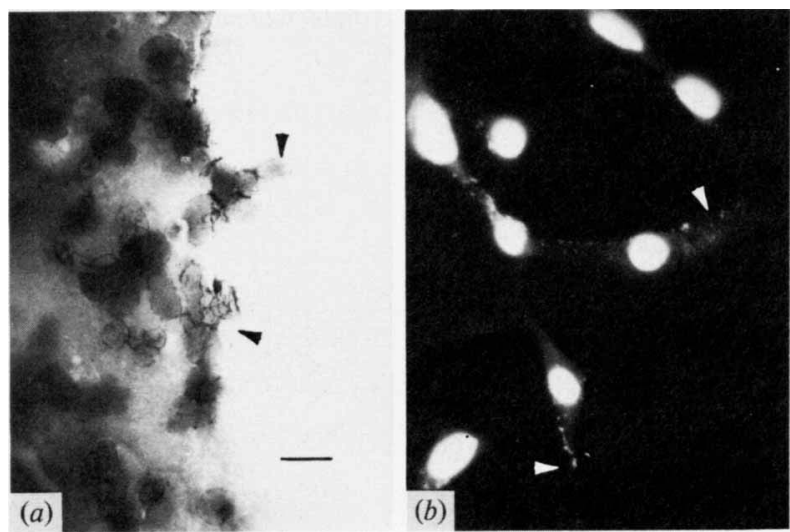

Fig. 4. Comparison between negative staining and Hoechst 33258 staining methods. Cells, line 640 3 Y 1-2, infected with mycoplasmas were examined. Distribution of mycoplasmas (arrow heads). The bar represents $1.0 \mu \mathrm{m}$ in $(a)$, and the original magnification is $\times 400$ in $(b)$. 
33258 staining procedure (Chen, 1977). The Hoechst staining method is a highly sensitive in situ procedure, and is widely used in many laboratories, but the ultrastructural features of mycoplasmas can not be resolved by this method. The negative staining method described here allows identification of single mycoplasmas at the ultrastructural level.

The investigations were supported in part by Grant-in-Aid for Cancer Research from the Ministry of Education, Science and Culture of the Japanese Government. We thank Dr D. Mrozek for helpful advice.

\section{REFERENCES}

BARILE, M. F. \& SCHRIMKE, R. T. (1963). A rapid chemical method for detecting PPLO contamination of tissue cell cultures. Proceedings of the Society for Experimental Biology 114, 676-679.

Barile, M. F., Malizia, W. \& Riggs, D. B. (1962). Incidence and detection of pleuropneumonia-like organisms in cell cultures by fluorescent antibody and cultural procedures. Journal of Bacteriology 84, 130-136.

Boatman, E. S. \& KenNy, G. E. (1971). Morphology and ultrastructure of Mycoplasma pneumoniae spherules. Journal of Bacteriology 106, 1005-1015.

Brown, S., Teplitz, M. \& Revel, J.-P. (1974). Interaction of mycoplasmas with cell cultures, as visualized by electron microscopy. Proceedings of the National Academy of Sciences of the United States of America 71, 464-468.

BuCKLEY, 1. K. \& PORTER, K. R. (1975). Electron microscopy of critical point dried whole cultured cells. Journal of Microscopy 104, 107-120.

Chen, T. R. (1977). In situ detection of mycoplasma contamination in cell cultures by fluorescent Hoechst 33258 stain. Experimental Cell Research 104, 255-262.

Hakala, M. T., Holland, J. F. \& Horoszewicz, J. S. (1963). Change in pyrimidine deoxyribonucleoside metabolism in cell culture caused by mycoplasma (PPLO) contamination. Biochemical and Biophysical Research Communications 11, 466-471.

ICHIMARU, H. \& Nakamura, M. (1979). The compo- nents of Mycoplasma salivarium and its growth medium that are responsible for film formation. Journal of General Microbiology 112, 389-392.

Katsumoto, T., Takayama, H. \& Takagi, A. (1978). Ultrastructural organization of cultured macrophages as shown by negative staining technique. Journal of Electron Microscopy 27, 1-11.

Kimura, G. \& ItAGaKI, A. (1975). Initiation and maintenance of cell transformation by simian virus 40: a viral genetic property. Proceedings of the National Academy of Sciences of the United States of America 72, 673-677.

MACPHERSON, I. (1966). Mycoplasmas in tissue culture. Journal of Cell Science 1, 145-168.

Nardone, R. M., Todd, J., Gonzalez, P. \& GafFNEY, E. V. (1965). Nucleoside incorporation into strain $L$ cells: inhibition by pleuropneumonia-like organisms. Science 149, 1100-1101.

Schneider, E. L., Stanbridge, E. J., Epstein, C. J., Golbus, M., Abbo-Halbasch, G. \& Rodgers, G. (1974). Mycoplasma contamination of cultured amniotic fluid cells: potential hazard to prenatal chromosomal diagnosis. Science 184, 477-480.

STANBRIDGE, E. (1971). Mycoplasmas and cell cultures. Bacteriological Reviews 35, 206-227.

Zucker-Franklin, D., Davidson, M. \& Thomas, L. (1966). The interaction of mycoplasmas with mammalian cells. I. HeLa cells, neutrophils, and eosinophils. Journal of Experimental Medicine 124, 521-541. 